\title{
LEMBAGA PENDIDIKAN ISLAM SEBAGAI WAHANA IMPLEMENTASI PENDIDIKAN ANTI KORUPSI
}

\author{
Much. Arif Saiful Anam \\ (Praktisi Pendidikan Islam di Nganjuk, Jawa Timur)
}

\begin{abstract}
Abstrak:
Korupsi tidak lagi sebagai suatu fenomena tetapi sudah mengakar ke seluruh lapisan masyarakat. Oleh karenanya, pada saat ini diperlukan kesadaran dari semua pihak untuk ikut serta berupaya memberantas, menghapus, atau minimalisir agar perilaku korupsi tidak semakin meluas dan mengakarnya. Upaya pencegahan budaya korupsi di masyarakat terlebih dahulu dapat dilakukan dengan mencegah berkembangnya mental korupsi pada anak bangsa Indonesia melalui pendidikan. Semangat antikorupsi yang patut menjadi kajian adalah penanaman pola pikir, sikap, dan perilaku antikorupsi melalui sekolah, karena sekolah adalah proses pembudayaan. Sektor pendidikan formal di Indonesia dapat berperan dalam memenuhi kebutuhan pencegahan korupsi. Langkah preventif (pencegahan) tersebut secara tidak langsung bisa melalui dua pendekatan (approach), pertama: menjadikan peserta didik sebagai target, dan kedua: menggunakan pemberdayaan peserta didik untuk menekan lingkungan agar tidak permissive to corruption. Implementasi pendidikan anti korupsi di madrasah harus mampu menciptakan situasi dan kondisi yang kondusif guna tercapainya lingkungan yang bebas korupsi dan terbentuknya generasi yang anti korupsi. Dengan ini, tindak korupsi yang sudah membudaya tersebut dapat diminimalisirkan. Adapun strategi pendidikan anti korupsi di madrasah dapat dijalankan melalui pembiasaan perilaku yaitu melalui implementasi budaya anti korupsi di madrasah.
\end{abstract}

Kata Kunci: Lembaga, Pendidikan, Islam, Budaya, Anti Korupsi. 


\begin{abstract}
:
It has widely spread among either central or local government officials. Hence, it is crucial to build the awareness of all parties to combat, eliminate, and fight any kinds of corruption The spirit of anti-corruption that should be studied are building a mindset, an attitude, and anticorruption behavior through school where a civilizing prosess occurs. Thus, formal education sector in Indonesia can play a role in meeting the needs of the prevention of corruption. There are two indirect preventive approaches. Firstly, set the learners as a target, and secondly empower learners to influence the society against corruption. Implementation of anti-corruption education in Madrasah should be able to create a conducive situation to reach a free of corruption environment and build generations of anti corruption. It can break the corruption chain. The main strategy of anti-corruption education in Indonesia can be run through implenting anti-corruption action in Madrasah.
\end{abstract}

\title{
Keywords: Institution, Education, Islam, Culture, Anti-Corruption.
}

\section{A. Pendahuluan}

Publikasi mengenai daftar negara terkorup di dunia yang mana Republik Indonesia menjadi salah satunya memang bisa menjadi sebuah stigma yang amat tidak nyaman bagi bangsa yang masih memiliki nurani. Negeri kita ini telah lama dikenal sebagai negeri yang kaya. Namun, pemerintahnya banyak utang dan rakyatnya pun terlilit dalam kemiskinan yamg akut. Sejak zaman pemerintahan kerajaan, kemudian zaman penjajahan, dan hingga zaman modern dalam pemerintahan NKRI dewasa ini, kehidupan rakyatnya tetap saja miskin. Akibatnya, kemiskinan yang berkepanjangan telah menderanya bertubi-tubi sehingga menumpulkan kecerdasan dan masuk terjerembab dalam kurungan keyakinan mistik, fatalisme, dan selalu ingin mencari jalan pintas.

Sungguh ironi permasalahan di negeri tercinta ini yang notabenya penduduk muslim terbesar di dunia ternyata masih terjadi korupsi, kini sudah menjadi permasalahan serius di negeri ini. Budaya korupsi sudah sangat mengakar dari generasi pendahulu sampai sekarang kasus korupsi sudah tidak terhitung lagi jumlahnya. Meskipun sudah ada Komisi Pemberantasan Korupsi (KPK) dan beberapa Instansi anti korupsi lainnya. Namun faktanya negeri ini 
masih menduduki rangking atas sebagai Negara terkorup didunia. Karena dari itu, korupsi patut menjadi perhatian serius bagi kita semua. ${ }^{1}$

Korupsi di negeri ini memang sudah merajalela bahkan telah menjadi suatu "budaya". Berbagai upaya telah dilakukan pemerintah dalam menangani korupsi bahkan dengan tindakan hukum yang sangat tegas. Namun, tetap saja korupsi masih terdapat di negeri ini. ${ }^{2}$ Salah satu mengapa orang berani melakukan tindak pidana korupsi yaitu karena kurangnya kesadaran pribadi tentang bahaya korupsi. Tentu saja kita tidak bisa menyadarkan para koruptor karena mereka sudah terlanjur terbiasa dengan tindakannya tersebut. Korupsi tidak hanya dilakukan oleh penyelenggara negara, antar penyelenggara negara, tetapi juga melibatkan pihak lain seperti keluarga, kroni dan para pengusaha, sehingga merusak sendi-sendi kehidupan bermasyarakat, berbangsa dan bernegara, yang dapat membahayakan eksistensi atas fungsi penyelenggaraan negara.

Langkah awal dan mendasar untuk menghadapi dan memberantas segala bentuk korupsi adalah dengan memperkuat landasan hukum yang salah satunya adalah dengan melakukan amandemen pada Undang-Undang Nomor 31 Tahun 1999 dan ditambah dengan Undang-Undang Nomor 20 Tahun 2001 tentang Pemberantasan Tindak Pidana Korupsi yang diharapkan dapat mendukung pembentukan pemerintahan yang bersih dan bebas korupsi, kolusi dan nepotisme, dan diperlukan pula kesamaan visi, misi dan persepsi aparatur penegak hukum dalam penanggulangannya. Kesamaan visi, misi dan persepsi tersebut harus sejalan dengan tuntutan hati nurani rakyat yang menghendaki terwujudnya penyelengara negara yang mampu menjalankan tugas dan fungsinya.

Lebih lanjut, Korupsi memang telah menjadi momok yang menakutkan bagi bangsa Indonesia, seperti yang kita ketahui bahwa Indonesia menduduki peringkat keenam sebagai negara terkorup dari 159 negara di dunia. Setelah berbagai usaha pemberantasan korupsi diambil oleh berbagai lembaga di Indonesia dengan hasil yang beragam, dunia pendidikan kini nampaknya mulai merasa bertanggung jawab akan pentingnya penanaman kesadaran melawan perilaku korupsi melalui institusi resmi sekolah yaitu pendidikan anti korupsi. ${ }^{3}$

\footnotetext{
${ }^{1}$ Kementrian Agama. Keputusan Direktur Jenderal Pendidikan Islam Nomor: 1696 Tahun 2013 Tentang Panduan Penyelenggaraan Pendidikan Anti Korupsi Di Madrasah Tahun 2013, (Jakarta: KEMENAG, 2013), 1.

2 Muhammad Azhar, Pendidikan Antikorupsi, (Yogyakarta: LP3 UMY, 2003) 12.

${ }^{3}$ Ajip Rosidi, Korupsi dan Kebudayaan, (Jakarta: Pustaka Jaya, 2006), 6.
}

Jurnal Pendidikan Agama Islam

Volume 3 Nomor 2 November 2015

ISSN: $2089-1946$

Hal. 370 - 392 
Wacana mengenai pendidikan anti korupsi didasarkan pertimbangan bahwa pemberantasan korupsi mesti dilakukan secara integratif dan simultan yang mesti berjalan beriringan dengan tindakan represif terhadap koruptor.

Jadi, salah satu upaya jangka panjang yang terbaik untuk mengatasi korupsi adalah dengan memberikan pendidikan anti korupsi dini kepada kalangan generasi muda sekarang. ${ }^{4}$ Karena generasi muda adalah generasi penerus yang akan menggantikan kedudukan para penjabat terdahulu. Juga karena generasi muda sangat mudah terpengaruh dengan lingkungan di sekitarnya. Jadi, kita lebih mudah mendidik dan memengaruhi generasi muda supaya tidak melakukan tindak pidana korupsi sebelum mereka lebih dulu dipengaruhi oleh "budaya” korupsi dari generasi pendahulunya.

\section{B. Korupsi}

\section{Pengertian Korupsi}

Menurut Puspito, dkk., kata "korupsi" berasal dari bahasa Latin "corruptio", yang secara harfiah, berarti kebusukan, keburukan, kebejatan, ketidakjujuran, dapat disuap, tidak bermoral, dan penyimpangan dari kesucian. 5 Di Malaysia korupsi disebut dengan "resuah" yang berasal dari bahasa Arab "risywah", kata tersebut memiliki arti suap menyuap yang identik dengan memakan barang yang diharamkan oleh Allah SWT. Mencari suap, menyuap dan menerima suap adalah haram, begitu juga dengan mediator antara penyuap dan yang disuap. ${ }^{6}$

Selanjutnya, terdapat beberapa pengertian lain di Indonesia yang berkaitan dengan korupsi, yaitu: ${ }^{7}$

a. Korup artinya busuk, suka menerima uang suap/sogok, memakai kekuasaan untuk kepentingan sendiri dan sebagainya.

\footnotetext{
${ }^{4}$ Andar Nubowo, Membangun Gerakan Antikorupsi Dalam Perspektif Pendidikan, (Yogyakarta: Lembaga Penelitian \& Pengembangan Pendidikan Universitas Muhammadiyah Yogyakarta, 2004), 34.

${ }^{5}$ Kementrian Agama. Keputusan Direktur Jenderal Pendidikan Islam Nomor: 1696 Tahun 2013 Tentang Panduan Penyelenggaraan Pendidikan Anti Korupsi Di Madrasah Tahun 2013, 5. Lihat juga Hakim Muda Harahab, Ayat-Ayat Korupsi, (Yogyakarta: Gama Media, 2009), 12. Nurdjana, Korupsi Dalam Praktek Bisnis, (Jakarta: Gramedia Pustaka, 2005), 7. Robert Klitgaard, Membasmi Korupsi, (Jakarta: Yayasan Obor Indonesia, 2001), 4.

6 Nanang T. Puspita, dkk, Pendidikan Anti Korupsi untuk Perguruan Tinggi, (Jakarta: Kemendikbud, 2011), 23-24. Lihat juga Abdullah Ibn Abd. Muhsin, Jaarimat ur Rasyiwaty fisy Syariiatil Islamiyyati: (Suap dalam Pandangan Islam) terj. Muchotob Hamzah, (Jakarta: Gema Insani Press, 2001), 6. Yusuf Qardhawi, Halal dan Haram Dalam Islam, (Surakarta: Indiva Media Kreasi, 2003), 462-463.

${ }^{7}$ Evi Hartanti, Tindak Pidana Korupsi Edisi Kedua, (Jakarta: Sinar Grafika, 2008), 8.
} 
b. Korupsi artinya perbuatan busuk seperti penggelapan uang, penerimaan uang sogok, dan sebagainya.

c. Koruptor artinya orang yang melakukan korupsi.

Dengan demikian, Puspito, dkk., menyimpulkan bahwa arti kata korupsi adalah sesuatu yang busuk, jahat dan merusak. Berdasarkan kenyataan tersebut perbuatan korupsi menyangkut sesuatu yang bersifat amoral, sifat, dan keadaan yang busuk, menyangkut jabatan instansi atau aparatur pemerintah, penyelewengan kekuasaan dalam jabatan karena pemberian, menyangkut faktor ekonomi dan politik dan penempatan keluarga atau golongan ke dalam kedinasan di bawah kekuasaan jabatan. ${ }^{8}$

Dari sudut pandang hukum, tindak pidana korupsi secara garis besar mencakup unsur-unsur sebagai berikut:

a. Perbuatan melawan hukum;

b. Penyalahgunaan kewenangan, kesempatan, atau sarana;

c. Memperkaya diri sendiri, orang lain, atau korporasi;

d. Merugikan keuangan negara atau perekonomian negara;

Selain itu terdapat beberapa jenis tindak pidana korupsi yang lain, di antaranya:

a. Memberi atau menerima hadiah atau janji (penyuapan);

b. Penggelapan dalam jabatan;

c. Pemerasan dalam jabatan;

d. Ikut serta dalam pengadaan (bagi pegawai negeri/penyelenggara negara);

e. Menerima gratifikasi (bagi pegawai negeri/penyelenggara negara). ${ }^{9}$

Korupsi berdasarkan pemahaman pasal 2 Undang-Undang Nomor 31

Tahun 1999 yang diubah menjadi Undang-Undang Nomor 20 Tahun 2001. Korupsi merupakan tindakan melawan hukum untuk memperkaya diri sendiri/orang lain (perseorangan atau sebuah korporasi), yang secara langusng maupun tidak langsung merugikan keuangan atau perekonomian negara, yang dari segi materiil perbuatan itu dipandang sebagai perbuatan yang bertentangan dengan nilai-nilai keadilan masyarakat. ${ }^{10}$

\footnotetext{
${ }^{8}$ Nanang T. Puspita, dkk, Pendidikan Anti Korupsi untuk Perguruan Tinggi, 23-24.

${ }^{9}$ Kementrian Agama. Keputusan Direktur Jenderal Pendidikan Islam Nomor: 1696 Tahun 2013 Tentang Panduan Penyelenggaraan Pendidikan Anti Korupsi Di Madrasah Tahun 2013, 5-6.

10 R. Wiyono, Pembahasan Undang-Undang Pemberantasan Tindak Pidana Korupsi, (Jakarta: Sinar Grafika, 2005), 18. Undang-Undang Republik Indonesia Nomor Nomor 31 Tahun 1999 tentang Pemberantasan Tindak Pidana Korupsi. Undang-Undang Republik Indonesia Nomor 20 Tahun 2001 tentang Perubahan atas Undang-Undang Republik Indonesia Nomor 31 Tahun 1999 tentang Pemberantasan Tindak Pidana Korupsi.
}

Jurnal Pendidikan Agama Islam

Volume 3 Nomor 2 November 2015

ISSN: $2089-1946$

Hal. 372 - 392 
Dalam arti yang lebih luas, korupsi atau korupsi politis adalah penyalahgunaan jabatan resmi untuk keuntungan pribadi. Semua bentuk pemerintah dalam pemerintahan rentan korupsi dalam prakteknya. Beratnya korupsi berbeda-beda, dari yang paling ringan dalam bentuk penggunaan pengaruh dan dukungan untuk memberi dan menerima pertolongan, sampai dengan korupsi berat yang diresmikan, dan sebagainya. Titik ujung korupsi adalah kleptokrasi, yang arti harfiahnya pemerintahan oleh para pencuri, dimana para pejabat pura-pura bertindak jujur padahal tidak ada sama sekali. ${ }^{11}$

Jika melihat dari pengertian korupsi diatas, bisa disimpulkan jika korupsi adalah sejenis penghianatan, dalam hal ini adalah penghianatan terhadap rakyat yang telah memberikan amanah dalam mengemban tugas tertentu. Dalam Al-Qur'an Allah SWT telah banyak mengingatkan manusia tentang hal ini. Antara lain:12

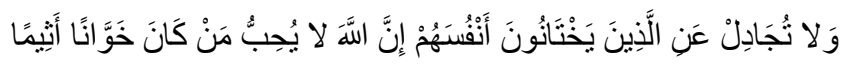

“Dan janganlah kamu berdebat (untuk membela) orang-orang yang mengkhianati dirinya. Sesungguhnya Allah tidak menyukai orang-orang yang selalu berkhianat lagi bergelimang dosa, (QS. An-Nisa'/4:107)".13

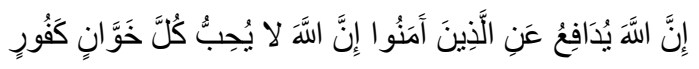

"Sesungguhnya Allah membela orang-orang yang Telah beriman. Sesungguhnya Allah tidak menyukai tiap-tiap orang yang berkhianat lagi mengingkari nikmat. (QS. Al-Hajj/22: 38)." 14

Melihat dari firman Allah SWT diatas, jelas jika Islam melarang segala bentuk penghianatan.

Allah SWT melarang Korupsi karena korupsi adalah salah satu bentuk penghianatan. Bahkan Rosulluloh menerangkan lebih rinci dalam hal ini. Beliau bersabda: "Terlaknatlah orang yang disuap dan yang menyuap" (HR. Ahmad)

\footnotetext{
${ }^{11}$ Hakim Muda Harahab, Ayat-Ayat Korupsi, 13.

12 Kementrian Agama. Keputusan Direktur Jenderal Pendidikan Islam Nomor: 1696 Tahun 2013 Tentang Panduan Penyelenggaraan Pendidikan Anti Korupsi Di Madrasah Tahun 2013, 7-8.

${ }^{13}$ Kementrian Agama RI, Al-Qur'an dan Terjemahnya, (Jakarta: Widya Cahaya, 2011), 172.

14 Ibid ,638.
} 
Much. Arif Saiful Anam

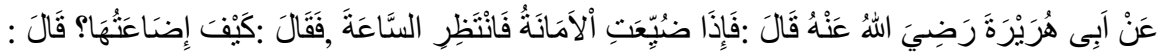

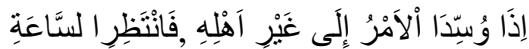

Dari Abu Hirairah ra., ia berkata bahwa Rasulullah saw. bersabda: "Jika amanah disia-siakan, maka tunggulah kehancuran. Kemudian dinyatakan: "bagaimana maksud amanah disia-siakan itu? Rasul menjawab: "Jika suatu perkara (amanat/ pekerjaan) diserahkan pada orang yang tidak ahli (profesional), maka tunggulah saat kehancuran" (HR. Bukhori). 15

Dalam ayat Al-Qur'an lain disebutkan:

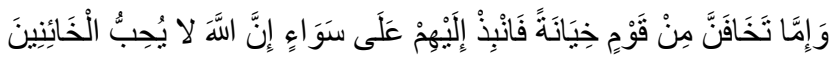

"Dan jika kamu khawatir akan (terjadinya) pengkhianatan dari suatu golongan, Maka kembalikanlah perjanjian itu kepada mereka dengan cara yang jujur. Sesungguhnya Allah tidak menyukai orang-orang yang berkhianat. (QS. Al-Anfal/8: 58)."16

Selain itu juga lebih ditegaskan lagi

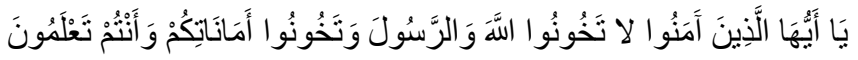

"Hai orang-orang yang beriman, janganlah kamu mengkhianati Allah dan Rasul (Muhammad) dan (juga) janganlah kamu mengkhianati amanat-amanat yang dipercayakan kepadamu, sedang kamu Mengetahui. (QS. Al-Anfal/8: 27)."17

Dalam Al-Qur'an dijelaskan jika manusia ingin diberi petunjuk, maka dia harus iman terhadap Al-Quran. Dalam ayat diatas dijelaskan jika kita harus takwa yaitu memelihara diri dari siksaan Allah dengan mengikuti segala perintah-perintah-Nya; dan menjauhi segala larangan-larangan-Nya. tidak cukup diartikan dengan takut saja. Maka dari itu, kitapun juga harus menjahui larangan Allah SWT berupa khianat atau korupsi. Allah SWT pun juga menegaskan lagi tentang hal tersebut.

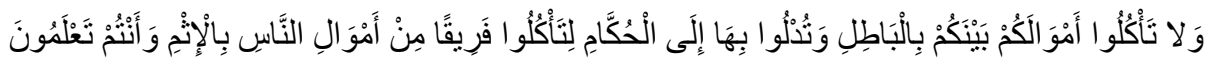

\footnotetext{
${ }^{15}$ Bukhari, Shahih Bukhari, Jilid I, (Beirut: Dar al-Fikr, 1420 H/2000 M), 29.

${ }^{16}$ Kementrian Agama RI, Al-Qur'an dan Terjemahnya, 340.

17 Ibid, 332.
} 
"Dan janganlah sebahagian kamu memakan harta sebahagian yang lain di antara kamu dengan jalan yang bathil dan (janganlah) kamu membawa (urusan) harta itu kepada hakim, supaya kamu dapat memakan sebahagian daripada harta benda orang lain itu dengan (jalan berbuat) dosa, padahal kamu Mengetahui." (QS. Al Baqarah/2: $188)^{18}$

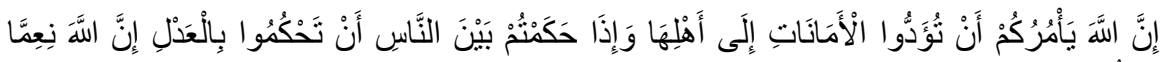

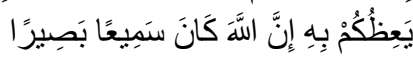

"Sesungguhnya Allah menyuruh kamu menyampaikan amanat kepada yang berhak menerimanya, dan (menyuruh kamu) apabila menetapkan hukum di antara manusia supaya kamu menetapkan dengan adil. Sesungguhnya Allah memberi pengajaran yang sebaik-baiknya kepadamu. Sesungguhnya Allah adalah Maha mendengar lagi Maha Melihat." (QS. An-Nisa/4: 58) ${ }^{19}$

Berkenaan tentang Pendidikan Anti Korupsi, maka kita patut menganalogikan hal tersebut. Jika Allah SWT mewajibkan sholat misalkan, maka kita harus belajar ilmu-ilmu sholat. Jika kita tidak belajar ilmu-ilmu sholat, mustahil kita bisa sholat dengan baik. Begitu pula ketika Allah SWT menyuruh umatnya untuk amanat. Maka kitapun harus belajar tentang amanat tersebut agar manusia senantiasa wara' dalam hidupnya.

Jadi, jika Allah SWT telah memberikan lampu merah pada perbuatan korupsi. Maka jelas ini adalah lampu hijau untuk menjalankan pendidikan anti korupsi. Seperti halnya pendidikan Islam yang didalamnya mengkaji segala kewajiban-kewajiban dan larangan manusia, maka jelas pendidikan anti korupsi perlu guna memberikan pemahaman lebih matang kepada umat manusia dalam bertindak amanah dan menjauhi khianat yang salah satu didalamnya adalah korupsi. Karena bukan tidak mungkin jika orang yang korupsi itu karena serakah, melainkan karena tidak memahami bentukbentuk dari korupsi itu sendiri.

18 Ibid, 52.

${ }^{19}$ Ibid, 158. 


\section{Ciri-Ciri Korupsi}

Ciri-ciri korupsi dijelaskan oleh Shed Husain Alatas dalam "Sosiologi Korupsi" sebagai berikut:20

a. Korupsi senantiasa melibatkan lebih dari satu orang. Hal ini tidak sama dengan kasus penipuan atau pencurian. Seorang operator yang korup sesungguhnya tidak ada dan kasus itu biasanya termasuk dalam pengertian penggelapan (fraud).

b. Korupsi pada umunya dilakukan secara rahasia, kecuali korupsi itu telah merajalela dan begitu dalam. Sehingga individu yang berkuasa dan mereka yang berada dalam lingkunganya tidak tergoda untuk menyembunyikan perbuatanya. Namun, walaupun demikian motif korupsi tetap dijaga kerahasiaanya.

c. Melibatkan elemen kewajiban dan keuntungan timbal balik.

d. Mereka yang mempraktekan korupsi biasanya berusaha untuk menyelubungi perbuatanya dengan berlindung dibalik pembenaran hokum.

e. Mereka yang terlibat korupsi, menginginkan keputusan yang tegas dan mampu untuk mempengaruhi keputusan-keputusan tersebut.

f. Setiap tindakan korupsi mengandung penipuan, biasanya dilakukan oleh badan public atau umum (masyarakat).

g. Setiap bentuk korupsi adalah suatu penghianatan kepercayaan.

\section{Faktor-Faktor Penyebab Korupsi}

Menurut Wahyudi \& Sopanah korupsi disebabkan oleh beberapa faktor, antara lain yaitu: ${ }^{21}$

a. Sistem pemerintahan dan birokrasi yang memang kondusif untuk melakukan penyimpangan.

b. Belum adanya sistem kontrol dari masyarakat yang kuat, dan belum adanya perangkat peraturan dan perundang-perundangan yang tegas.

c. Tindak lanjut dari setiap penemuan pelanggaran yang masih lemah dan belum menunjukkan "greget" oleh pimpinan instansi.

Sedangkan Puspito, dkk. merumuskan beberapa aspek penyebab korupsi yang terbagi dalam dua faktor, yaitu faktor internal dan faktor

${ }^{20}$ Hussain Alatas, Sosiologi Korupsi: Sebuah Penjelajahan Dengan Data Kontemporer, (Jakarta: LP3ES, 1982), 9-10.

21 Sopanah dan Isa Wahyudi, Analisa Anggaran Publik: Panduan TOT, (Jakarta: Malang Corruption Watch (MCW) dan Yappika, 2004), 20-21. 
eksternal. Berikut adalah faktor internal yang merupakan faktor pendorong korupsi dari dalam diri, dapat dirinci sebagai berikut: ${ }^{22}$

a. Aspek Perilaku Individu

Aspek ini ditandai dengan perilaku individu yang memiliki sifat tamak/rakus, moral yang kurang kuat, dan gaya hidup yang konsumtif.

b. Aspek Sosial

Perilaku korup dapat terjadi karena dorongan keluarga. Kaum behavioris mengatakan bahwa lingkungan keluargalah yang secara kuat memberikan dorongan bagi orang untuk korupsi.

Kemudian faktor eksternal yang merupakan pemicu perilaku korup yang disebabkan oleh faktor di luar diri pelaku adalah:

a. Aspek Sikap Masyarakat Terhadap Korupsi

Sikap masyarakat yang berpotensi menyuburkan tindak korupsi terjadi karena nilai-nilai di masyarakat kondusif untuk terjadinya korupsi, masyarakat kurang menyadari bahwa korban utama korupsi adalah masyarakat sendiri, masyarakat kurang menyadari bila dirinya terlibat korupsi, dan Masyarakat kurang menyadari bahwa korupsi akan bisa dicegah dan diberantas bila masyarakat ikut aktif dalam agenda pencegahan dan pemberantasan.

b. Aspek Ekonomi

Pendapatan tidak mencukupi kebutuhan. Dalam rentang kehidupan ada kemungkinan seseorang mengalami situasi terdesak dalam hal ekonomi. Keterdesakan itu membuka ruang bagi seseorang untuk mengambil jalan pintas diantaranya dengan melakukan korupsi.

c. Aspek Politis

Instabilitas politik, kepentingan politis, meraih dan mempertahankan kekuasaan sangat berpotensi menyebabkan perilaku korupsi.

d. Aspek Organisasi

Penyebab korupsi yang termasuk dalam aspek organisasi adalah kurang adanya sikap keteladanan pimpinan, tidak adanya kultur organisasi yang benar, kurang memadainya sistem akuntabilitas, kelemahan sistim pengendalian manajemen, dan lemahnya pengawasan.

Dari beberapa penjelasan di atas mengenai faktor-faktor penyebab korupsi, maka dapat dibuat suatu kesimpulan bahwa penyebab utama korupsi adalah perilaku individu itu sendiri. Apabila individu tersebut memiliki cara pandang yang menyimpang dalam melihat kekayaan, maka hal itu dapat mendorong individu untuk melakukan korupsi. Individu yang

22 Nanang T. Puspita, dkk, Pendidikan Anti Korupsi untuk Perguruan Tinggi, 47-49. 
termasuk dalam golongan tersebut adalah mereka yang bersifat tamak, kurang iman, dan konsumtif.

Kemudian perilaku individu tersebut didukung dengan adanya kesempatan. Kesempatan itu dapat berasal dari beberapa aspek, seperti kesempatan yang timbul dari lingkungan atau organisasi yang cenderung mendukung terjadinya korupsi. Selanjutnya kesempatan yang timbul dari aspek politik, yaitu dengan adanya kecurangan untuk melakukan politik uang dengan tujuan tertentu. Aspek hukum juga bisa mendukung terjadinya korupsi, seperti yang telah disebutkan sebelumnya, bahwa lemahnya peraturan perundang-undangan dan lemahnya penegakan hukum dapat memberikan kesempatan bagi para pelaku korupsi. Berikutnya yaitu aspek ekonomi, meskipun rendahnya tingkat gaji bukan alasan mutlak seseorang melakukan korupsi, namun dalam keadaan tertentu hal tersebut mungkin terjadi. Dikatakan bukan merupakan faktor mutlak karena selama ini banyak sekali ditemukan para pelaku korupsi yang telah memiliki jumlah kekayaan melimpah, tapi tetap melakukan korupsi. ${ }^{23}$

\section{Bentuk/Jenis Korupsi}

Setidaknya terdapat 6 (enam) bentuk-bentuk korupsi menurut KPK (2006), keenam bentuk korupsi tersebut yaitu:

a. Perbuatan melawan hukum, memperkaya diri orang/badan lain yang merugikan keuangan/perekonomian negara.

b. Menyalahgunakan kewenangan karena jabatan/kedudukan yang dapat merugikan keuangan/perekonomian negara.

c. Penggelapan dalam jabatan.

d. Pemerasan dalam jabatan.

e. Tindak pidana yang berkaitan dengan pemborongan.

f. Delik gratifikasi. ${ }^{24}$

\section{Dampak Korupsi}

Ada beberapa dampak yang ditimbulkan oleh korupsi, menurut bidangnya:

a. Dampak terhadap perekonomian 25

\footnotetext{
${ }^{23}$ Ibid, 49.

24 Doni Muhardiansyah, dkk., Buku Saku Memahami Gratifikasi, (Jakarta: Komisi Pemberantasan Korupsi Republik Indonesia, 2010), iii.

25 Nanang T. Puspita, dkk, Pendidikan Anti Korupsi untuk Perguruan Tinggi, 55.
} 
Banyak kerugian yang ditimbulkan akibat korupsi. Diantaranya seperti yang terdapat dalam Pasal 2 ayat (1) UU PTPK "Setiap orang yang secara melawan hukum melakukan perbuatan memperkaya diri sendiri atau orang lain atau suatu korporasi yang dapat merugikan keuangan negara atau perekonomian negara, dipidana dengan pidana penjara seumur hidup atau pidana penjara paling singkat 4 (empat) tahun dan paling lama 20 (dua puluh) tahun dan denda paling sedikit RP. 200.000.000,00 (satu miliar rupiah).26. Adapun secara rinci dampak korupsi terhadap aspek ekonomi antara lain:

1) Memotong investasi dan produk national bruto

2) Mengikat persaingan bebas dan mengakibatkan perusahaan besar merusak perusahaan kecil

3) Penurunan daya saing, kualitas barang dan jasa buruk

4) Penurunan kepercayaan investor asing, perekonomian menurun.

5) meningkatnya biaya barang dan jasa, yang kemudian dapat melonjakkan utang Negara.

b. Dampak terhadap pemerintahan Negara

1) Investasi rendah, efisiensi kerja menurun

2) Mendorong demoralisasi pegawai, promosi tidak terkait dengan kualitas pekerjaan

3) Pemerintahan menjadi lemah dan terbatas

4) Keegoisan pejabat publik membayang-bayangi pemikiran strategis kebutuhan negara, oleh karena itu, masalah ekonomi dan sosial kurangnya menjadi perhatian yang layak;

c. Dampak Sosial dan Kemiskinan Masyarakat ${ }^{27}$

Bagi masyarakat miskin, korupsi mengakibatkan dampak yang luar biasa dan saling bertaut satu sama lain. Pertama, dampak langsung yang dirasakan oleh orang miskin yakni semakin mahalnya jasa berbagai pelayanan publik, rendahnya kualitas pelayanan, dan pembatasan akses terhadap berbagai pelayanan vital seperti air, kesehatan, dan pendidikan. Kedua, dampak tidak langsung terhadap orang miskin yakni pengalihan sumber daya milik publik untuk kepentingan pribadi dan kelompok, yang seharusnya diperuntukkan guna kemajuan sektor sosial dan orang miskin, melalui pembatasan pembangunan. Hal ini secara langsung memiliki pengaruh kepada langgengnya kemiskinan yang dapat menimbulkan solidaritas social

${ }^{26}$ R. Wiyono, Pembahasan Undang-Undang Pemberantasan Tindak Pidana Korupsi, 27.

27 Nanang T. Puspita, dkk, Pendidikan Anti Korupsi untuk Perguruan Tinggi, 58. 
semakin langka dan demoralisasi serta dapat meningkatkan angka kriminalitas.

d. Dampak Terhadap Politik dan Demokrasi28

Dampak masif korupsi terhadap politik dan demokrasi antara lain memunculkan kepemimpinan korup karena kondisi politik yang carut marut dan cenderung koruptif, hilangnya kepercayaan publik pada demokrasi karena terjadinya tindak korupsi besar-besaran yang dilakukan oleh petinggi pemerintah, legislatif, yudikatif atau petinggi partai politik, menguatnya plutokrasi (sistem politik yang dikuasai oleh pemilik modal/kapitalis), dan hancurnya kedaulatan rakyat yang disebabkan kekayaan negara hanya dinikmati oleh sekelompok tertentu.

e. Dampak terhadap Penegakan Hukum

Dampak masif korupsi terhadap penegakan hukum dapat dirasakan antara lain fungsi pemerintahan yang mandul karena korupsi mengikis banyak kemampuan pemerintah untuk melakukan fungsi yang seharusnya, hilangnya kepercayaan rakyat terhadap lembaga negara karena bobroknya penegakan hukum di Indonesia. Seharusnyalah pemerintah menciptakan keteraturan dalam kehidupan berbangsa dan bernegara dan bukan sebaliknya.

f. Dampak Terhadap Pertahanan dan Keamanan

Dampak masif korupsi terhadap pertahanan dan keamanan antara lain dapat mengakibatkan kerawanan HANKAMNAS karena lemahnya alutsista dan sumber daya manusia, lemahnya garis batas Negara karena kemiskinan yang terjadi di daerah perbatasan negara, menguatnya sisi kekerasan dalam masyarakat karena kondisi kemiskinan pada akhirnya memicu berbagai kerawanan sosial lainnya yang semakin membuat masyarakat frustasi menghadapi kerasnya kehidupan.

g. Dampak Kerusakan Lingkungan ${ }^{29}$

Dampak masif korupsi juga dapat mengakibatkan kerusakan lingkungan yang ditandai dengan menurunnya kualitas lingkungan karena adanya ekslpoitasi besar besaran sumber daya alam, menurunnya kualitas hidup yang juga akan berdampak pada menurunnya kualitas hidup manusia yang ada di dalamnya, serta kualitas hidup global.

${ }^{28}$ Ibid, 63.

${ }^{29}$ Ibid, 64-68.

Jurnal Pendidikan Agama Islam

Volume 3 Nomor 2 November 2015

ISSN: 2089-1946

Hal. 380 - 392 


\section{Pendidikan Anti Korupsi sebagai Upaya Pencegahan dan Pemberantasan Korupsi}

Pendidikan sebagai wahana untuk membentuk generasi penerus bangsa menjadi wadah yang efektif dalam rangka pencegahan korupsi. Pemberantasan korupsi tidak cukup dengan menghukum dan memberikan ceramah atau seminar anti korupsi. Agar tidak terjadi tumbuh silih bergantinya korupsi di Indonesia, maka perlu dicari sampai dari akar masalahnya. Dengan membekali pendidikan anti korupsi yang cukup akan memberikan perlindungan kepada para calon generasi penerus bangsa dari maraknya tindak korupsi.

Kemudian muncul pertanyaan mulai kapan pendidikan antikorupsi harus dikenalkan kepada anak? Jawabnya adalah sejak anak belajar tentang kehidupan, artinya sejak awal anak lahir mulai dikenalkan nilai-nilai anti korupsi.

Penanaman nilai yang dilakukan secara konsisten dan berkelanjutan, akan menumbuhkan sebuah sikap yang menjadi kepribadian anak. Pada dasarnya sebuah kepribadian seseorang tidak muncul secara instan namun melalui sebuah proses.

Tujuan dari pendidikan anti-korupsi sendiri adalah untuk membangun nilai-nilai dan mengembangkan kapasitas yang diperlukan untuk membentuk posisi sipil murid dalam melawan korupsi. ${ }^{30}$ Untuk mencapai tujuan ini, siswa harus:

1. Memahami informasi

Bahaya korupsi biasanya ditunjukkan menggunakan argument ekonomi, sosial dan politik. Siswa tentunya akan sulit untuk memahaminya, untuk itu perlu 'diterjemahkan' ke dalam bahasa para siswa dengan menunjukkan bagaimana korupsi mengancam kepentingan mereka dan kepentingan keluarga dan teman-teman.

2. Mengingat

Tidak diragukan lagi, dengan proses mengulang, anak akan ingat, namun jika hal yang sama diulang lebih dari tiga kali, anak akan merasa jenuh dan merasa kehilangan hak untuk membuat pilihan bebas. Jadi tidak ada salahnya mengubah bentuk penyediaan informasi dengan cara yang paling tak terduga dan mengesankan (ada variasi).

3. Mempersuasi (Membujuk) diri sendiri untuk bersikap kritis

Sikap kritis menjadi sangat kuat bila tidak hanya diberikan, tetapi mengarahkan mereka untuk mengembangkanya dengan penalaran intensif. Efeknya akan lebih kuat jika menggunakan metode pembelajaran aktif.

${ }^{30}$ Kementrian Agama. Keputusan Direktur Jenderal Pendidikan Islam Nomor: 1696 Tahun 2013 Tentang Panduan Penyelenggaraan Pendidikan Anti Korupsi Di Madrasah Tahun 2013, 6. 
Pengenalan Pendidikan Anti Korupsi ini tentunya harus bertahap sesuai dengan usia anak. Usia anak dan remaja merupakan usia yang cukup kritis dalam pembentukan sikap, sehingga dapat dikatakan bahwa untuk memperbaiki negara ini (mungkin butuh waktu 20 tahunan) pendidikan anti korupsi di tingkat SD dan SMP menjadi penting untuk menyiapkan pemimpin masa depan yang tidak korup.

Pertanyaannya:

a. Bagaimana Pendidikan Anti Korupsi diterapkan?

Pendidikan Anti Korupsi bisa dilaksanakan baik secara formal maupun informal. Ditingkat formal, unsur-unsur pendidikan anti korupsi dapat dimasukkan kedalam kurikulum diinsersikan/ diintegrasikan ke dalam matapelajaran. Untuk tingkat informal dapat dilakukan dalam kegiatan ekstrakurikuler.

b. Mengapa pendidikan berbasis nilai menjadi penting dalam Pendidikan Anti Korupsi ?

Dalam beberapa hari, harian kompas mengulas tentang seminar Korupsi dan Kemiskinan. Jika dicermati dari tulisan-tulisan yang termuat dalam harian kompas tersebut, maka akar menyadari korupsi yang membusukkan negara dan memiskinkan rakyat tersebut terjadi karena kerusakan moral yang cukup parah dan mengakar yang seolah sudah membudaya pada para pejabat publik yang ada. Pada tulisan disebutkan bahwa pembentukan karakter bangsa menjadi penting, dan pendidikan selama ini dirasa hanya berperan dalam mencerdaskan bangsa dalam ranah koginitf saja. Lalu bagaimana seharusnya? Sudah saatnya bahwa pendidikan lebih diarahkan pada keseimbangan antara kecerdasan kognitif dan kecerdasan mental. Untuk itu pendidikan berbasis nilai (value based education) menjadi penting untuk dilakukan. Mendidik siswa yang utuh, pintar dan berkepribadian.

c. Nilai-Nilai apa yang perlu ditanamkan?

Secara universal ada beberapa nilai yang dapat membentuk karakter anak menjadi lebih baik, seperti: ${ }^{31}$
1) Kejujuran
2) Kepedulian dan menghargai sesama
3) Kerja keras
4) Tanggungjawab
5) Kesederhanaan
6) Keadilan

31 Ibid, 9. 
7) Disiplin

8) Kooperatif

9) Keberanian

10) Daya juang/ kegigihan

Dengan mengintegrasikan nilai-nilai ini kedalam kehidupan/proses belajar siswa diharapkan siswa mampu berkembang menjadi pribadi yang lebih baik, dan akhirnya akan bersikap anti koruptif. Penanaman nilai ini tidak sebatas pada insersi mata pelajaran, tetapi perlu diberikan disemua lini pendidikan. Nilai ini hendaknya selalu direfleksikan kedalam setiap proses pembelajaran baik yang bersifat intra kurikuler maupun ekstra kurikuler.

d. Mengapa guru berperan penting dalam Pendidikan Anti Korupsi di Sekolah?

Guru adalah garda depan dari proses pendidikan, maka selayaknyalah guru menjadi teladan (digugu dan ditiru). Selain sebagai teladan, guru juga mempunyai tugas penting sebagai motivator. Dalam Pendidikan Anti Korupsi guru berperan dalam:

1) Mengenalkan fenomena korupsi, esensi, alasan, dan konsekuensinya

2) Mempromosikan sikap intoleransi terhadap korupsi

3) Mendemontrasikan cara memerangi korupsi (sesuai koridor anak)

4) Memberi kontribusi pada kurikulum standar dengan:

- Penanaman nilai-nilai

- Penguatan kapasitas siswa (seperti: berpikir kritis, tanggungjawab, penyelesaian konflik, memanage dirinya sendiri, dalam berkehidupan sosial disekolah-masyarakat- lingkungan, dll) dengan menghayati dan melaksanakan tugas ini, Indonesia akan menjadi negara besar dan bersih, serta makmur dibawah pimpinan murid-murid yang telah di didik sedemikian rupa).

\section{Pendidikan Anti Korupsi di Lembaga Pendidikan Islam}

Dalam prakteknya, korupsi sangat sukar bahkan hampir tidak mungkin dapat diberantas, oleh karena sangat sulit memberikan pembuktian-pembuktian yang eksak. Disamping itu, sangat sulit mendekteksinya dengan dasar-dasar hukum yang pasti. Namun akses perbuatan korupsi merupakan bahaya latent yang harus diwaspadai baik oleh pemerintah maupun oleh masyarakat itu sendiri.

Salah satu cara atau langkah yang harus dilakukan oleh pemerintah maupun masyarakat adalah memberikan informasi serta perlunya edukasi akan 
nilai anti korupsi yang disampaikan melalui jalur pendidikan, sebab pendidikan merupakan satu instrumen perubahan yang mengedepankan cara damai, menjauhkan diri dari tarik menarik politik pragmatis, relative sepi dari caci maki dan hujatan sosial, berawal dari pembangkitan kesadaran kritis serta sangat potensial untuk bermuara pada pemberdayaan dan transformasi masyarakat berdasarkan model penguatan inisiatif manusiawi dan nuraniah untuk suatu agenda perubahan sosial. ${ }^{32}$

"Education is a mirror society", pendidikan adalah cermin masyarakat. Artinya, kegagalan pendidikan berarti kegagalan dalam masyarakat. Demikian pula sebaliknya, keberhasilan pendidikan mencerminkan keberhasilan masyarakat. Pendidikan yang berkualitas akan menciptakan masyarakat yang berkualitas pula.

Sebagai upaya pemberantasan korupsi, pemerintah melalui KPK (Komisi Pemberantasan Korupsi) kini berjuang keras menangkap pelaku korupsi. Namun upaya pemberantasan dengan menangkap pelaku korupsi dirasa belum cukup. Pun, sosialisasi pemberantasan korupsi tidak cukup sekedar memberi pemahaman apa itu korupsi.

Ada satu hal yang tidak kalah penting dalam pemberantasan korupsi, yakni pencegahan korupsi. Pencegahan menjadi bagian penting dalam program pemberantasan korupsi. Oleh sebab itu, pencegahan korupsi harus diajarkan disetiap jenjang pendidikan.

Mengapa demikian? sebab, pertama, korupsi hanya dapat dihapuskan dari kehidupan kita secara berangsur-angsur. Kedua, pendidikan untuk membasmi korupsi sebaiknya berupa persilangan (intersection) antara pendidikan watak dan pendidikan kewarganegaraan. Ketiga, pendidikan untuk mengurangi korupsi harus berupa pendidikan nilai, yaitu pendidikan untuk mendorong setiap generasi menyusun kembali sistem nilai yang diwarisi. ${ }^{33}$

Sangat mungkin korupsi dihapus melalui sector pendidikan, apabila kita bersungguh-sungguh bertekad memberantas korupsi dari berbagai aspek kehidupan, bukan hanya pada tingkat lembaga atau organisasi-organisasi yang besar, tetapi juga pada tingkat interaktif sesama manusia termasuk dalam proses belajar dari generasi muda.

Hal ini dimungkinkan karena korupsi termasuk pelanggaran moral dan oleh sebab itu merupakan tanggung jawab moral dari pendidikan nasional untuk memberantasnya. Selain itu proses pendidikan merupakan proses pembudayaan. Jika korupsi telah menjadi kebudayaan dalam diri masyarakat Indonesia, maka

\footnotetext{
${ }^{32}$ Abu Fida' Abdur Rafi', Terapi Penyakit Korupsi (Jakarta: Republika, 2006), xxii.

33 Mochtar Buchori, Pendidikan Antikorupsi, Kompas, 4 Meret 2007.
} 
adalah tanggung jawab moral dari pendidikan nasional untuk membenahi pendidikan nasionalnya dalam upaya pemberantasan korupsi.

Lebih lanjut, sektor pendidikan formal di Indonesia, memiliki kedudukan strategis-antisipatif dalam upaya pencegahan korupsi. Langkah preventif pencegahan tersebut secara tidak langsung dapat dilakukan melalui dua pendekatan (approach), yaitu:

1. Menjadikan peserta didik menjadi target

2. Menggunakan pemberdayaan peserta didik untuk menekan lingkungan agar tidak permissive to corruption.

Gerakan anti korupsi perlu ditanamkan sejak dini kepada anak didik, agar generasi muda penerus bangsa tumbuh menjadi SDM berkualitas serta memiliki moral yang terpuji. Inilah yang biasanya disebut dengan "memberantas korupsi sampai ke akar-akarnya". ${ }^{34}$

Dan tidak mau ketinggalan Pendidikan Islam mencoba menampilkan model pendidikan anti korupsi dalam Pendidikan Agama Islam (PAI). Pendidikan anti korupsi yang dimaksud disini adalah program pendidikan anti korupsi yang secara konsepsional disisipkan pada mata pelajaran yang sudah ada disekolah dalam bentuk perluasan tema yang sudah ada dalam kurikulum dengan menggunakan pendekatan kontekstual pada pembelajaran anti korupsi, yaitu dengan model pendidikan anti korupsi integratif-inklusif dalam Pendidikan Agama Islam.

Untuk berpartisipasi dalam gerakan pencegahan dan pemberantasan korupsi ada dua model yang dapat dilakukan oleh sekolah dalam mengembangkan kurikulum pendidikan anti korupsi yang integratif-inklusif pada Pendidikan Agama Islam.

1. Proses pendidikan harus menumbuhkan kepedulian sosial-normatif, membangun penalaran objektif, dan mengembangkan perspektif universal pada individu.

2. Pendidikan harus mengarah pada penyemaian strategis, yaitu kualitas pribadi individu yang konsekuen dan kokoh dalam keterlibatan peran sosialnya.

Bagaimana cara mensosialisasikan anti koruspi pada anak sejak dini? Salah satu jawabanya adalah mengajarkan sikap jujur dan bertanggung jawab kepada diri sendiri. Orang tua atau guru harus menjadi teladan bagi anak atau siswanya.

Dalam pembelajaran, diperlukan prinsip modeling. Artinya, siswa atau anak dengan mudah akan melakukan suatu perilaku tertentu melalui

${ }^{34}$ Andar Nubowo, Membangun Gerakan Antikorupsi Dalam Perspektif Pendidikan, 34. 
proses peniruan pada sang model. Model ini bisa siapapun, apakah itu orang tua, guru, maupun orang-orang yang dikaguminya.

Pendidikan Islam Anti Korupsi, tidak cukup hanya sampai disini. Pemberantasan korupsi harus memiliki basis teologis. Nilai nilai ajaran Islam juga perlu ditekankan dan dikontekstualisasikan secara lebih dan ekstra. Misalnya saja dengan mensosialisasikan hadist-hadist anti korupsi seperti hadist tentang menjaga amanah. Sebagaimana yang diketahui bersama bahwa semua tindakan korupsi dimulai dari penyalahgunaan amanah (abuse of trust), yang menjalar menjadi penyalahgunaan kekuasaan atau wewenang (abuse of power), baik dalam urusan individu maupun publik. Amanah diyakini sebagai benteng anti korupsi yang sangat kuat. Jika benteng amanah telah rusak, maka yang lain pun akan rusak. Rasulullah SAW bersabda tentang pentingnya jujur dan menjaga amanah:

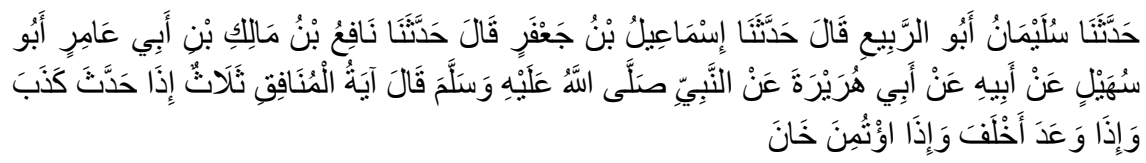

“Sulaiman Abu Rabi' telah menceritakan hadist kepada kami, Ismail Ibnu Ja'far telah menceritakan hadist kepada kami, Nafi' Ibnu Malik Ibnu Abi Amir, yaitu Abi Suhail, telah menceritaka hadist kepada kami dari Bapaknya dari Abi Hurairah dari Nabi bersabda: " Tanda-tanda orang munafik ada tiga: jika berbicara berdusta, jika berjanji ingkar, jika dipercaya berhianat." (HR. Bukhari).

Hadits ini sangat tegas dan lugas bahwa kejujuran, keterbukaan, dan tanggung jawab adalah tanda-tanda pokok keimanan yang harus dipelihara. Tanpa ketiga hal tersebut, walaupun telah memperbanyak ibadah ritual, seseorang layak disebut munafik. Betapa banyak orang yang berjanji ketika kampanye politik, bersumpah ketika hendak memangku sebuah jabatan, berpidato berapi-api dalam sambutan pelantikan, tetapi semuanya hanya tinggal janji, sumpah palsu dan omong kosong. Kursi kekuasaan seringkali membuat orang lupa pada janji dan sumpah jabatan yang disaksikan orang banyak serta disaksikan oleh Allah SWT. Harta berlimpah seringkali membutakan mata, menulikan telinga, dan menumpulkan akal budi, sehingga kepercayaan public yang dibangun sejak lama pun dikorbankan.

Tindakan korupsi sangat bertentangan dengan prinsip amanah dan kejujuran yang diajarkan dalam agama. Lebih jelas lagi, Rasulallah SAW 
berpesan tentang akibat pelanggaran atau penyalahgunaan amanah, yaitu sebuah kerusakan total sistem kehidupan masyarakat. Pernyataan Rasulallah SAW ini terbukti ketika banyak pejabat pemegang amanah menyeleweng, semua sistem sosial kemasyarakatan lambat laun menjadi rusak.

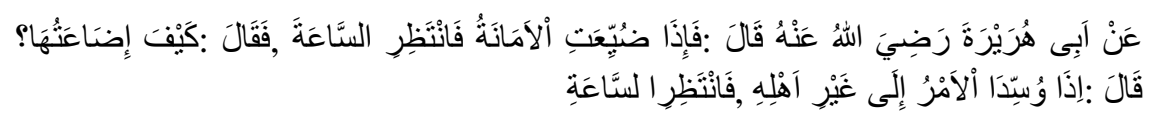

Dari Abu Hirairah ra., ia berkata bahwa Rasulullah saw. bersabda: "Jika amanah disia-siakan, maka tunggulah kehancuran. Kemudian dinyatakan: "bagaimana maksud amanah disia-siakan itu? Rasul menjawab: "Jika suatu perkara (amanat/ pekerjaan) diserahkan pada orang yang tidak ahli (profesional), maka tunggulah saat kehancuran" (HR. Bukhori). 35

Dari hadist diatas, hubungan antara amanah dan keahlian sangatlah erat. Jika keduanya hilang, maka kehancuran akan mengancam. Dan salah satu factor yang dapat merusak amanah dan profesionalitas adalah suap. Seseorang yang sebelum menjabat, mungkin tantangan berlaku jujur mungkin tidak berat. Namun ketika sudah menjabat/ menduduki jabatan tertentu, tawaran suap sulit dihindari. Disinilah amanah seorang pejabat diuji.

Dalam hadist lain, Rasulallah SAW menegaskan hubungan iman dengan amanah dan kaitan ketat amanah dengan pemenuhan janji.

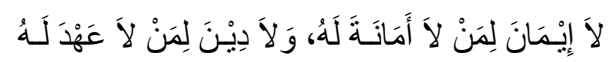

"Tidak beriman (tidak sempurna iman) orang yang tidak menjaga amanah dan tidak beragama (tidak sempurna agama) seseorang yang tidak menepati janjinya." (HR. Ahmad)

Hadist diatas menjelaskan bahwa iman harus dibuktikan dengan sikap amanah dalam interaksi sosial.

Tanpa sikap amanah, iman menjadi rusak sehingga rasa aman menjadi hilang. Lebih jelasnya, jika kecurangan dan korupsi disemua lini, iman dan amanah sudah tidak ada, maka keamanan menjadi problem yang sulit dikendalikan. Akhirnya, kejahatan merajalela dan hukumpun tidak berdaya, karena jika amanah telah tiada, maka hukum dan keadilan dapat diperjualbelikan. Selanjutnya, rusaklah tata kehidupan masyarakat dan sendisendi bangsa negara.

35 Bukhari, Shahih Bukhari, Jilid I, (Beirut: Dar al-Fikr, 1420 H/2000 M), 29. 
Menanamkan nilai-nilai keislaman yang anti korupsi, baik dari AlQur'an maupun sejarah Islam, dalam proses pemberantasan korupsi akan lebih efektif dan mengena. Karena nilai-nilai tersebut terkandung dalam kitab tuntunan yang diyakini kebenaranya oleh seluruh umat Islam.

\section{E. Impelementasi Budaya Anti Korupsi Bagi Manajerial Madrasah}

Pendidikan adalah usaha sadar yang membentuk watak dan prilaku secara sistematis, terencana, dan terarah. Madrasah adalah lembaga pendidikan yang memasukan nilai-nilai Islam baik dalam kurikulum pembelajarannya maupun dalam etika sehari hari. Untuk itu Madrasah harus bisa menjadi model percontohan dalam menegakkan Amar ma'ruf nahi munkar, khususnya untuk tindak pidana korupsi pada penyelenggaraan pendidikan.

Islam memerintahkan umatnya agar hanya memakan dan memakai harta yang halal. Halal dan haram tidak hanya ditentukan dari dzatnya saja, melainkan juga bagaimana cara memperolehnya. Korupsi menurut kesepakatan Ulama (ijma) merupakan suatu tindakan yang sangat diharamkan oleh Islam. Maka dari itu sangatlah penting untuk menanamkan budaya anti korupsi di lingkungan madrasah.

Ciri khas madrasah lebih dari hanya sekedar penyajian mata pelajaran agama. Artinya, ciri khas tersebut bukan hanya sekedar menyajikan mata pelajaran agama Islam di dalam lembaga madrasah tetapi yang lebih penting ialah perwujudan dari nilai-nilai keislaman di dalam totalitas kehidupan madrasah. ciri khas tersebut mengandung unsur-unsur sebagai berikut: (1) Perwujudan nilai-nilai keislaman di dalam keseluruhan kehidupan lembaga madrasah; (2) Kedidupan moral yang beraktuaisasi, dan (3) Manajemen yang profesional, terbuka, dan berperan aktif dalam masyarakat. ${ }^{36}$ Artinya mulai dari Kepala Madrasah hingga tukang sapu madrasah bersama -sama menciptakan budaya anti korupsi di lingkungan madrasah.

Seorang kepala madrasah merupakan penentu kebijakan pada madrasah tempatnya bertugas. Penerapan budaya anti korupsi di madrasah memang sudah seharusnya di laksanakan dan seorang kepala madrasah wajib menjadi motor penggerak dan tauladan bagi segenap civitas akademika madrasah. Peran penting seorang kepala madrasah menjadi tumpuan bagi gerakan anti korupsi di madrasah. Tak hanya sebagai tauladan, seorang kepala madrasah juga beperan sebagai pegendali sistem birokrasi di madrasah. Dituntut ketegasan dan kreatifitas seorang kepala madrasah dalam menjalankan sistem dan kebijakan

36 H.A.R. Tilaar, Multikulturalisme Tantangan-tantangan Global Masa Depan dalam Transformasi Pendidikan Nasional. (Jakarta: Grasindo, 2004), 179.

Jurnal Pendidikan Agama Islam

Volume 3 Nomor 2 November 2015

ISSN: $2089-1946$

Hal. 388 - 392 
yang bebas dari korupsi. Hal tersebut bisa di lakukan misalnya dengan melakukan kebijakan reward and punishment, sebagai stimulus bagi seluruh murid, guru (ustadz) dan karyawan di madrasah. Dan untuk mengefektifkan program tersebut dibutuhkan pula sistem pengawasan internal. Sebagai kepala madrasah tentunya dibutuhkan pribadi yang jujur, bersih dan berani serta memiliki komitmen yang kuat untuk membudayakan anti korupsi dalam menerapkan kebijakan - kebijakan tersebut di madrasah.

Peran para guru (ustadz) juga tak kalah penting dalam membudayakan anti korupsi di lingkungan madrasah. Karena mereka yang berhubungan langsung dengan para murid, setiap tindakan dan ucapan mereka sangat berpengaruh terhadap tingkah laku serta pribadi murid - murid madrasah. Maka dari itu peran seorang guru (ustadz) selain dituntut untuk mempropagandakan slogan-slogan anti korupsi kepada murid - murid madrasah, mereka juga harus mengimplementasikan dalam setiap pelaksanaan proses belajar mengajar dan dalam setiap prilaku sehari -hari. Dimulai dari hal terkecil seperti kepatuhan terhadap peraturan yang dibuat oleh pihak madrasah, misalnya tepat waktu, kehadiran dan lain sebagainya.

Hal selanjutnya yang juga tak kalah penting adalah birokrasi dalam penyelenggaraan pendidikan di madrasah. Hal yang sering terjadi adalah membudayanya pungutan - pungutan liar yang dilakukan pihak sekolah, pemberian gratifikasi para wali murid kepada guru atau bahkan kepala sekolah dengan modus mempermudah segala urusan yang membelit siswa. Disini peran orang tua atau wali murid juga dibutuhkan agar tidak membudayakan kegiatan yang seperti itu. Peran orang tua atau wali murid juga dibutuhkan untuk mengawasi segala bentuk kebijakan madrasah yang merugikan pihak siswa.

Ada satu moment dimana madrasah justru menjadi pelaku tindak ketidak jujuran, yaitu saat pelaksanaan Ujian Nasional (UN). Pihak sekolah atau madrasah, dengan dalih agar para siswanya dapat lulus seratus persen, melakukan praktik - yang tidak terpuji dan tidak mendidik, dengan cara memberikan jawaban kepada siswa yang melakukan Ujian Nasional (UN). Dalam hal ini madrasah sebagai lembaga pendidikan yang menanamkan nilai - nilai ke Islaman harus menjadi contoh untuk menghindari usaha-usaha yang tercela tersebut dengan meningkatkan kualitas pengajaran agar para siswa bisa mencapai hasil maksimal tanpa melakukan praktik - praktik tak terpuji tersebut, bukan justru ikut -ikutan melakukan hal serupa.

Dalam mewujudkan budaya anti korupsi di madrasah memang butuh dukungan dari semua pihak. Mulai dari Kepala sekolah, Guru (Ustadz), pegawai, siswa dan orang tua atau wali murid, bahkan sampai tukang sapu madrasah 
sekalipun. Karena bukan hanya membawa citra personal dan madrasah itu sendiri, tapi juga citra Islam.

Sebagai langkah pemberantasan korupsi di negeri ini telah dibentuk Komisi Pemberantasan Korupsi (KPK) yang banyak melakukan penanggulangan korupsi secara represif. Namun terbukti hingga saat ini tindakan represif masih belum memberikan efek jera terhadap para pelaku korupsi. Agar perilaku korupsi tidak semakin meluas, diperlukan tindakan pencegahan (preventif) terhadap potensi untuk melakukan tindakan korupsi. Salah satu cara yang dapat dilakukan adalah dengan menanamkan budaya anti korupsi dalam kehidupan sehari-hari.

Pada lingkungan Madrasah, penanaman budaya anti korupsi dapat dilaksanakan dalam tataran pelaksanaan keadministrasian dan managerial di Madrasah. Disadari ataupun tidak, banyak sekali potensi perilaku korupsi pada tataran managerial Madrasah. Adapun beberapa kegiatan yang mungkin dapat dilakukan untuk menanamkan budaya anti korupsi adalah:

1. Transparansi: a). APBS dibuat secara bersama dengan melibatkan guru, komite Madrasah, orang tua, dan staf TU. b). Pamflet-pamflet serta laporanlaporan yang dibuat secara tertulis oleh Madrasah secara formal. Selama proses penyusunan RPS dan APBS, para guru, perwakilan orang tua, pengurus komite Madrasah dan staf Madrasah selalu dilibatkan secara aktif, meskipun tidak semua guru dan staf dilibatkan secara total.

2. Partisipasi: para warga Madrasah dan stakeholders lainnya harus berpartisipasi aktif dalam pengelolaan Madrasah dalam berbagai bentuk semisal sumbangsih pemikiran, keterlibatan guru, staf, dan orang tua siswa dalam kegiatan Madrasah. Secara formal penyampaian aspirasi (sebagai salah satu bentuk partisipasi) dilakukan melalui rapat, sedangkan secara informal dilakukan dengan bertatap muka dengan kepala Madrasah ataupun melalui surat.

3. Akuntabilitas: perlu dimilikinya standar kerja yang jelas dalam bentuk TUPOKSI (tugas pokok dan fungsi), evaluasi kinerja melalui pemeriksaan dokumen rencana pembelajaran, kunjungan kelas oleh kepala Madrasah, dan konsultasi individu antara guru dan kepala Madrasah.

Implementasi dari transparansi, partisipasi, dan akuntabilitas akan berjalan dengan baik bila didukung dengan: a). dorongan dari orang tua siswa, b). personil Madrasah telah memiliki kualifikasi yang cukup, d). adanya media komunikasi yang mampu menjadi penyalur berbagai informasi perkembangan Madrasah, masukan serta kritikan dari stakeholder, dan e). program-program 
Madrasah mendukung terhadap pengimplementasi-an pemberantasan korupsi, kolusi dan nepotisme.

\section{F. Penutup}

Korupsi merupakan masalah yang sifatnya sangat kompleks, sehingga memerlukan pemecahan secara sistematik dalam berbagai bidang. Dengan demikian, pendidikan dapat menjadi salah satu alternatif pemecahan dalam melakukan upaya pemberantasan korupsi, dengan mengintegrasikan materimateri anti korupsi ke dalam kurikulumnya. Pemberantasan korupsi bukan hanya menyangkut bagaimana menangkap dan memidsiswaan pelaku tindak pidana korupsi, tapi lebih jauh adalah bagaimana mencegah tindak pidana korupsi agar tidak terulang pada masa yang akan datang.

Internalisasi nilai-nilai Islami dapat menjadi solusi alternatif antisipatif dalam membentuk kesadaran antikorupsi anak didik di sekolah/madrasah Pendidikan Agama di lembaga pendidikan yang diolah kembali menjadi pendidikan etika-sosial yang menekankan perlunya akutabilitas publik baik dalam rancangan pembelajaran maupun implementasinya dapat juga menjadi alternatif dalam menyelesaikan masalah-masalah moral yang terjadi dalam masyarakat kita, termasuk masalah Pemberantasan Korupsi. Oleh karena itu, pendidikan anti korupsi tidak hanya sekedar wacana, tetapi ia harus menjadi pendidikan yang berorientasi pada praktek. Untuk melihat urgensi budaya anti korupsi di dalam masyarakat dan melihat betapa rumit dan bahayanya praktek korupsi, para anak didik dapat diajak untuk selalu membudayakan budaya anti korupsi dalam kehidupan sehari-hari

Dengan adanya pendidikan antikorupsi ini, diharapkan akan lahir generasi tanpa korupsi sehingga dimasa yang akan datang tercipta Indonesia yang bebas dari korupsi. Harapan awal tentunya ini akan berdampak langsung pada lingkungan sekolah/madrasah yaitu pada semua elemen pendidikan, seperti kepala sekolah, guru, karyawan dan anak didik. Lingkungan sekolah akan menjadi pionir bagi pemberantasan korupsi dan akan merembes ke semua aspek kehidupan bangsa demi mewujudkan Indonesia yang bebas dari korupsi.

\section{G. Daftar Pustaka}

Alatas, Hussain. 1982. Sosiologi Korupsi: Sebuah Penjelajahan Dengan Data Kontemporer. Jakarta: LP3ES.

Azhar, Muhammad. 2003. Pendidikan Antikorupsi. Yogyakarta: LP3 UMY.

Buchori, Mochtar. 2007. Pendidikan Antikorupsi. Kompas. Edisi 4 Maret 2007.

Bukhari. 1420 H/2000 M. Shahih Bukhari. Jilid I. Beirut: Dar al-Fikr.

Harahab, Hakim Muda. 2009. Ayat-Ayat Korupsi. Yogyakarta: Gama Media. 
Hartanti, Evi. 2008. Tindak Pidana Korupsi. Jakarta: Sinar Grafika.

Kementrian Agama. 2013. Keputusan Direktur Jenderal Pendidikan Islam Nomor: 1696 Tahun 2013 Tentang Panduan Penyelenggaraan Pendidikan Anti Korupsi Di Madrasah Tahun 2013. Jakarta: KEMENAG. . 2011. Al-Qur'an dan Terjemahnya. Jakarta: Widya Cahaya.

Klitgaard, Robert. 2001. Membasmi Korupsi, Jakarta: Yayasan Obor Indonesia.

Komisi Pemberantasan Korupsi (KPK). 2006. Memahami untuk Membasmi: Buku Saku untuk Memahami Tindak Pidana Korupsi. Jakarta: Komis Pemberantasan Korupsi.

Muhardiansyah, Doni dkk., 2010. Buku Saku Memahami Gratifikasi. Jakarta: Komisi Pemberantasan Korupsi.

Nanang T. Puspita, dkk. 2011. Pendidikan Anti Korupsi untuk Perguruan Tinggi. Jakarta: Kemendikbud.

Nubowo, Andar. 2004. Membangun Gerakan Antikorupsi Dalam Perspektif Pendidikan. Yogyakarta: Lembaga Penelitian \& Pengembangan Pendidikan Universitas Muhammadiyah Yogyakarta.

Nurdjana. 2005. Korupsi Dalam Praktek Bisnis. Jakarta: Gramedia Pustaka.

Qardhawi, Yusuf. 2003. Halal dan Haram Dalam Islam. Surakarta: Indiva Media Kreasi.

Rafi', Abu Fida'Abdur. 2006. Terapi Penyakit Korupsi. Jakarta: Republika.

Rosidi, Ajip. 2006. Korupsi dan Kebudayaan. Jakarta: Pustaka Jaya.

Sopanah dan Isa Wahyudi. 2004. Analisa Anggaran Publik: Panduan TOT. Jakarta: Malang Corruption Watch (MCW) dan Yappika.

Tilaar, H.A.R. 2004. Multikulturalisme Tantangan-tantangan Global Masa Depan dalam Transformasi Pendidikan Nasional. Jakarta: Grasindo.

Undang-Undang Republik Indonesia Nomor Nomor 31 Tahun 1999 tentang Pemberantasan Tindak Pidana Korupsi.

Undang-Undang Republik Indonesia Nomor 20 Tahun 2001 tentang Perubahan atas Undang-Undang Republik Indonesia Nomor 31 Tahun 1999 tentang Pemberantasan Tindak Pidana Korupsi.

Wiyono, R. 2005. Pembahasan Undang-Undang Pemberantasan Tindak Pidana Korupsi. Jakarta: Sinar Grafika. 